\title{
PENTINGNYA INVESTASI DI KABUPATEN WONOGIRI GUNA MENUNJANG PEREKONOMIAN MASYARAKAT WONOGIRI
}

\author{
Ahmad Khusnur Almursyidi
}

M0218004

Jurusan Fisika,Fakultas MIPA,Universitas Sebelas Maret

Jl. Ir. Sutami No.36 A,57126

\section{PENDAHULUAN}

\section{A. Latar Belakang}

Permasalahan yang dialami masyarakat kita khususnya wonogiri tak lain dan tak bukan tentang perekonomian.Selain itu masih berkurangnya kebutuhan fasilitas kota wonogiri seperti sekolah, puskesmas,rumah sakit,jembatan,jalan raya hotel,mall, dan lain-lain.Hal ini didasari dengan belum adanya suntikan modal atau pinjaman dari pihak masyarakat kepada pemerintah daerah agar melengkapi fasilitas kota.Oleh karena itu,di usulkan agar diadakannya penyuluhan atau edukasi kepada masyarakat tentang arti pentingnya investasi demi menunjang perekonomian mereka.

Dengan berkontribusi melalui investasi,maka secara langsung akan meningkatkan taraf hidup masyarakat karena dengan investasi modal yang dibutuhkan pemerintah untuk meningkatkan fasilitas kota tercukupi.

Konsep pengedukasian investasi ini diharapkan agar mampu menambah minat masyarakat akan investasi dan dapat berinvestasi hingga taraf nasional seperti investasi saham,resakdana,obligasi dan pasar uang.

\section{B. Tujuan dan Manfaat}

Dari masalah-masalah yang telah diuraikan, maka dapat diketahui tujuan

dari gagasan ini, yaitu :

1. Pemberian layanan edukasi yang merata sebagai solusi untuk menambah ilmu ekonomi di kalangan masyarakat Wonogiri. 
2. Masyarakat dapat langsung berinvestasi baik di dalam tingkat kabupaten maupun tingkat nasional.

Adapun manfaat yang ingin diperoleh dari gagasan ini,yaitu :

1. Bagi penulis,gagasan ini dapat menambah wawasan dan pengetahuan terkait masalah yang diangkat.

2. Masyarakat mendapatkan ilmu baru untuk berinvestasi.

3. Masyarakat dapat langsung mempraktekan dan merasakan manfaat langsung dari imbal hasil investasi.

\section{GAGASAN}

\section{A. Kondisi Masyarakat Wonogiri mengenai Investasi}

Perkembangan perekonomian sebuah kota dipengaruhi oleh banyaknya peran dari Pemerintah dan keikutsertaan masyarakat dalam membangun sebuah kota.Tercatat bahwa pertumbuhan perekonomian Indonesia pada tahun 2018 naik hingga mencapai 5,17\% (I Gusti Ayu Purnamawati, 2013).Dari sejumlah strategi menumbuhkan ekonomi nasional,investasi digadang dapat menjadi kunci pertumbuhan ekonomi (Rahma, 2019).

Menurut Bupati Wonogiri,ciri-ciri kota sukses adalah daerah yang ramah investasi.Dia mempersilakan siapa pun dapat berinvestasi baik dari kalangan masyarakat wonogiri maupun luar daerah wonogiri (Hartono, 2018).

Namun pada tahun 2018,tercatat angka kemiskinan di Wonogiri masih sangat tinggi yaitu 10\% (Asmara, 2018).Sehingga upaya peningkatan perekonomian yang menjadi fokus pemerintah daerah Wonogiri adalah peningkatan sarana infrastruktur dan pendidikan (Wakhidah, 2018).

\section{B. Upaya Yang Dilakukan}

Adapun upaya yang ditawarkan berupa penyuluhan atau pemberian edukasi di setiap kecamatan yang membahas tentang perekonomian baik mikro maupun makro.Dan juga pengenalan tentang instrumen investasi pembangunan tingat daerah dan tingkat nasional seperti saham,resakdana,obligasi,dan pasar uang. 


\section{Penyuluhan dan Pengenalan Investasi}

Tindakan nyata berupa pengedukasian di tiap kecamatan dirasa efektif dalam meningkatkan minat belajar tentang perekonomian dan penyebaran minat untuk berinvestasi.Anak muda di tiap kecamatan diharapkan ikut serta agar mereka terlatih berpikir rasional atau jangka panjang demi perekonomian kedepan.

Pengenalan instrumen investasi diantaranya tingkat kabupaten dengan ikut serta menanamkan modal untuk pembangunan fasilitas daerah dengan peran serta pemerintah agar tidak mengandalkan suntikan dana dari luar daerah.

Pengenalan instrumen investasi selanjutnya yaitu investasi saham,resakdana,obligasi dan pasar uang.Edukasi benar-benar difokuskan dari bagaimana memulainya,cara memilih instrumen dengan benar,keuntungan yang diperoleh dari berinvestasi,serta faktor - faktor yang paling berpengaruh berupa risiko berinvestasi, tingkat pendapatan (modal), motivasi, pengetahuan tentang investasi, persepsi, dan belajar di pasar modal (Malik, 2017).

\section{Pihak-Pihak Yang Dapat Membantu Mengimplementasikan Gagasan}

Gagasan ini akan terwujud bila adanya pihak yang bersedia membantu kami dalam memberikan edukasi yakni pemerintah daerah,pakar ekonom,masyarakat,dan lain-lain.Hal ini harus terus dilakukan agar kita tidak menjadi warga negara yang buta kondisi perekonomian bangsa dan berupaya mengentaskan kemiskinan.

\section{E. Langkah-Langkah Strategis Yang Diperlukan}

Proposal ini adalah salah satu langkah strategis agar dapatmengimplementasikan gagasan ini.Diharapkan Pemerintah dapat membaca proposal ini dan dapat dipertimbangkan dalam merencanakan gagasan berikut.

\section{KESIMPULAN}

\section{A. Penyuluhan dan Pengenalan Investasi}

Edukasi atau penyuluhan akan efektif membantu memberikan ilmu baru tentang mikro dan makro ekonomi dalam hal ini yaitu investasi. 


\section{B. Teknik Implementasi Gagasan}

Edukasi atau penyuluhan di tiap kecamatan di Kabupaten Wonogiri yang terlibat didalamnya masyarakat terutama anak muda daerah.

C. Prediksi Hasil Yang Akan Dicapai

Diharapkan keluaran dari penyuluhan ini masyarakat dapat mengaplikasikan dengan berinvestasi baik dari daerah hingga nasional. 


\section{DAFTAR PUSTAKA}

Asmara, T. (2018). Angka Kemiskinan di Wonogiri Menurun.Diperoleh dari https://timlo.net/baca/15911/angka-kemiskinan-di-wonogiri-menurun/. Surakarta: Timlo.net.

Hartono, R. (2018). IVESTASI PABRIK SEMEN,Wonogiri Tunggu Langkah Konkret.Diperoleh dari https://m.bisnis.com/semarang/read/20180104/536/757002/investasi-pabrik-semenwonogiri-tunggu-langkah-konkret. Semarang: Bisnis.com.

I Gusti Ayu Purnamawati, D. N. (2013). FAKTOR FUNDAMENTAL EKONOMI MAKRO TERHADAP. Jurnal Keuangan dan Perbankan, 211-219.

Malik, A. D. (2017). ANALISA FAKTOR - FAKTOR YANG MEMPENGARUHI MINAT MASYARAKAT BERINVESTASI DI PASAR MODAL SYARIAH MELALUI BURSA GALERI INVESTASI UISI. Jurnal Ekonomi dan Bisnis Islam, 61-84.

Rahma, A. (2019). Investasi Jadi Kunci Pertumbuhan Ekonomi.Diperoleh dari https://m.liputan6.com/bisnis/read/3938209/investasi-jadi-kunci-pertumbuhanekonomi. Indonesia: liputan6.com.

Wakhidah, H. A. (2018). Tekan Kemiskinan,Wonogiri Mesti Pro Investasi.Diperoleh dari https://m.solopos.com/soloraya/read/20180809/495/933086/tekan-kemiskinanwonogiri-mesti-pro-investasi. Soloraya: Solopos.com. 